\title{
Membangun Kemandirian Financial Pada Masyarakat Melalui Pelatihan Kewirausahaan Menggunakan Media Sosial
}

\author{
${ }^{1 *}$ Al Fitriyah, ${ }^{2}$ Destiara Ika Utami, ${ }^{3}$ Shanya Egha Heriyanto Putri, ${ }^{4}$ Siti Anisa Fauziatul \\ Hasanah \\ Universitas Pamulang, Tangerang Selatan, Indonesia \\ *alfitriyah14@gmail.com
}

\begin{abstract}
Abstrak
Perkembangan teknologi saat ini semakin canggih dan bertumbuh. Hal ini tentu telah mengubah segala aspek kehidupan masyarakat, termasuk bidang perekonomian. Salah satu faktor pendukung perekonomian suatu negara adalah kewirausahaan. Dengan adanya kegiatan wirausaha ini diharapkan masyarakat mampu mendorong untuk lebih kreatif serta dapat meningkatkan perekonomian masyarakat menjadi lebih mandiri secara financial. Saat ini teknologi sudah dapat dimanfaatkan dan memudahkan dalam berwirausaha. Aplikasi media sosial seperti whatsapp dan instagram saat ini sangat membantu sebagai media promosi untuk berbisnis. Aplikasi tersebut tidak hanya terkenal dalam kalangan muda-mudi, faktanya saat ini ibu-ibu pun mengenal aplikasi tersebut yang dijadikan wadah dalam berjualan online. Kegiatan Pengabdian Masyarakat yang dilakukan pada tanggal 16 Oktober 2021 ini dilakukan dalam rangka sosialisasi dalm penggunaan media online untuk ibu-ibu PKK di Kelurahan Pondok Pinang, Jakarta Selatan. Sosialisasi ini dilakukan dengan menggunakan metode klasikal dengan penyampaian materi, serta sharing pengalaman ibu-ibu agar dapat termotivasi dalam membangun kemandirian finansial.
\end{abstract}

Kata Kunci: Kewirausahaan, Kemandirian Finansial, Masyarakat

Abstract

The development of technology is currently increasingly sophisticated and growing. This certainly has changed all aspects of people's lives, including the economy. One of the factors supporting the economy of a country is entrepreneurship. With this entrepreneurial activity, it is hoped that the community will be able to encourage them to be more creative and be able to improve the community's economy to become more financially independent. Currently, technology can be utilized and facilitates entrepreneurship. Social media applications such as WhatsApp and Instagram are currently very helpful as promotional media for business. The application is not only famous among young people, the fact is that currently mothers are also familiar with the application which is used as a forum for selling online. This Community Service activity which was carried out on October 16, 2021, was carried out in the context of socializing the use of online media for PKK mothers in Pondok Pinang Village, South Jakarta. This socialization was carried out using the classical method with the delivery of material, as well as sharing the experiences of mothers so that they could be motivated in building financial independence.

Keywords: Entrepreneurship, Financial Independence, Society

\section{PENDAHULUAN}

Perkembangan teknologi saat ini semakin canggih dan bertumbuh. Teknologi diciptakan untuk membantu manusia dalam meringankan beban aktivitas serta membantu dalam memberikan informasi yang cepat, tepat dan akurat. Hal ini tentu telah mengubah segala aspek kehidupan masyarakat, termasuk bidang perekonomian. Salah satu faktor pendukung perekonomian suatu negara adalah kewirausahaan. Wirausaha merupakan salah satu cikal bakal bagi setiap daerah untuk menghasilkan nilai tambah dalam menyikapi beragam ketersediaan potensi sumber daya atas produk atau jasa yang ada. Dengan adanya kegiatan wirausaha ini diharapkan masyarakat mampu mendorong untuk lebih kreatif serta dapat meningkatkan perekonomian masyarakat menjadi lebih mandiri secara financial. Teknologi yang ada sekarang dapat dimanfaatkan dan memudahkan wirausaha dalam melayani permintaan konsumen yang 
begitu kompleks dan mendorong pelaku usaha untuk lebih kreatif dalam meningkatkan merek produknya agar lebih terkenal dikalangan masyarakat serta mampu memasarkan produknya secara digital untuk menjangkau konsumen lebih luas lagi. Penjualan produk secara digital atau sering disebut dengan jual beli online. Jual beli online ini menjadi familiar saat ini karena akses yang mudah dengan difasilitasi oleh internet via media social yang berkembang beberapa tahun blakangan ini (Yeti et al, 2021).

Usaha dalam kegiatan jual beli online ini merupakan salah satu yang dilakukan untuk mendapatkan hasil dengan tujuan yang telah ditentukan. Dengan usaha ini masyarakat akan mendapatkan hasil untuk memenuhi kebutuhannya. Masyarakat dapat memanfaatkan jejaring sosial melalui whatsapp, instagram, dan lainnya. Media sosial yang lebih mudah untuk digunakan saat ini diberbagai dikalangan yaitu whatsapp dan instagram dalam membantu kegiatan bisnisnya. Aplikasi ini banyak sekali digunakan karna mimiliki fitur yang mudah untuk membuka media promosi. Dengan melatih diri berwirausaha ini dapat mengembangkan potensi diri dan dapat menjalin sebuah hubungan lebih dekat dengan pengguna lainnya. Menurut Gondokusumo, (2016) jejaring sosial ini memungkinkan untuk berbagi informasi bahkan menjadi media dalam mempromosikan dan membangun image yang baik terhadap calon pelanggan dalam menjual produknya. dengan adanya hubungan dan komunikasi ini dapat mengetahui apa yang menjadi kebutuhan dan keinginan para konsumennya.

Sekarang ini media sosial tidak hanya diminati oleh anak muda saja untuk melakukan sebuah bisnis, tetapi diminati juga oleh ibu-ibu rumah tangga yang memiliki potensi untuk mengembangkan usahannya dari rumah. Biasanya ibu-ibu ini ingin mendapatkan penghasilan tambahan melalui membuka usaha sendiri dirumah sekaligus mengurus rumah tanggannya. Dan berpikir untuk membuka usaha apa yang cocok untuk semua kalangan contohnya seperti produk fashion dll. Berdasarkan penjelasan diatas, dalam kegiatan Pengabdian Masyarakat ini, pelaksana ining mensosialisasikan dalam pemanfaatan jejaring sosial terutama whatsapp dan instagram dalam mempromosikan produknya, yaitu dengan sasaran ibu-ibu PKK di Kelurahan Pondok Pinang, Jakarta Selatan. Dengan adanya pelatihan ini, sangat diharapkan ibu-ibu PKK ini dapat lebih mengetahui dalam penggunaan whatsapp dan Instagram ini dalam kegiatan bisnis, serta memberikan inspirasi dan motivasi untuk membangun financial secara mandiri dengan berjualan secara online.

Adapun rumusan masalah dalam kegiatan ini, yaitu: 1) apakah ibu-ibu PKK di Kelurahan Pondok Pinang, Jakarta Selatan telah mengenal dalam menggunakan jejaring sosial dalam kehidupan sehari-hari?, 2) Apakah ibu-ibu PKK ini sudah mengetahui teknik dalam memasarkan barang melalui jejaring sosial?, 3) apakah kegiatan pelatihan dapat memberikan sebuah inspirasi mengenai peluang bisnis yang dapat dilakukan dengan memanfaatkan jejaring sosial, bagi ibu-ibu PKK di Kelurahan Pondok Pinang yang belum memiliki usaha? tujuan dengan adanya kegiatan Pengabdian Masyarakat ini, yaitu :1) Memperkenalkan kepada ibu-ibu PKK di Kelurahan Pondok Pinang tentang jejaring sosial dan juga cara penggunaanya dikehidupan sehari-hari, 2) memberikan sebuah bimbingan tentang manfaat jejaring sosial whatsapp sebagai sarana yang lebih mudah untuk mempromosikan dan memasarkan produknnya, 3) memberikan semangat dan pengetahuan kewirausahaan, agar ibu-ibu PKK yang hanya dirumah saja dapat memanfaatkan jejaring sosial yang digunakan sehari-hari dalam membantu meningkatkan kebutuhan ekonomi keluarga.

\section{METODE PELAKSANAAN}

Kegiatan Pengabdian Masyarakat ini dilakukan untuk mensosialisasikan bagaimana penggunaan jejaring sosial whatsapp di kalangan ibu-ibu PKK di Kelurahan Pondok Pinang, Jakarta Selatan. Dalam kegiatan ini juga unruk mengarahkan ibu-ibu PKK yang sebagian besar seorang ibu rumah tangga untuk melakukan usaha/bisnis dari rumah. Pelatihan ini berfokus pada bagaimana tata cara untuk memasarkan sebuah produk melalui jejaring sosial. sangat diharapkan untuk kegiatan ini memberikan inspirasi dan juga masukan kepada ibu-ibu untuk lebih berfikir kreatif dan menggali potensi yang ada. Tahapan yang dilakukan dalam pelatihan menggunakan jejaring sosial whatsapp dalam memasarkan produk/barang mencakup analisis kebutuhan, yaitu : a) beberapa masih ada ibu-ibu PKK yang belum bisa untuk mengoperasikan aplikasi jejaring 
sosial dikehidupan sehari-hari, b) beberapa ibu-ibu PKK ada yang sudah memiliki bisnis rumahan, tetapi belum menggunakan jejaring sosial, sehingga membutuhkan metode lain dalam memasarkan produknya terutama melalui jejaring sosial untuk meningkatkan daya saing usahannya, c) ibu-ibu PKK ini sangat membutuhkan pengetahuan bagaimana tata cara memanfaatkan jejaring sosial dalam mendukung bisnisnya, seperti memposting dan menulis caption untuk menarik calon pelanggan, cara merespon dan berinteraksi, dan sebagainnya.

Tahapan selanjutnya dengan mempertimbangkan beberapa aspek materi untuk program pelatihan yang dibuat dengan kebutuhan peserta, tim pelaksana membuat materi, yang dibagi menjadi: a) Materi yang membahas tentang tips bagaimana menjadi pribadi yang mendiri secara finansial; b) Penerapan Perencanaan dalam Keuangan (Financial Planning); c) Langkah-langkah menjadi wirausaha; d) Penerapan pemasaran melalui media sosial (seperti whatsapp, facebook, instagram, dll); e) Tips and Trick dalam menarik perhatian calon pelanggan. Dalam kegiatan PMKM ini, tim pelaksana sharing kepada ibu-ibu PKK dengan bantuan dari pengalaman salah satu anggota tim kami yang sedang merintis usahanya di bidang online melalui media sosial.

Guna mencapai tujuan agar acara dapat berjalan dengan lancar dan sesuai dengan keinginan, kami melakukan beberapa tahapan yang meliputi: a) Perizinan kepada ketua RT setempat dalam melaksanakan kegiatan PMKM di wilayah RT010/RW01; b) melakukan survey yang sekiranya dibutuhkan dalam pelaksanaan kegiatan dan melakukan koordinasi kepada ibuibu PKK dalam kepastian kehadiran dalam pengabdian ini serta menentukan waktu dan seberapa lama kegiatan akan berlangsung; c) Melakukan perekrutan peserta dengan memilih ibu-ibu PKK yang sekiranya paham dan mengenal sosial media.

Harapan tim pelaksana ibu-ibu PKK tidak hanya mendengarkan materi saja, tetapi dapat sharing pengalaman juga. Kegiatan pengabdian masyarakat telah dilaksanakan pada hari Sabtu, tanggal 16 Oktober 2021, mulai dari pukul $10.00 \mathrm{~s} / \mathrm{d}$ selesai, dihadiri oleh 10 peserta. Peserta pada pelatihan ini terdiri dari para pengurus PKK, dan ibu-ibu anggota PKK yang ada di Kelurahan Pondok Pinang, Jakarta Selatan.

Dalam evaluasi akhir tim pelaksana melihat pencapaian yang ada sebagai berikut: a) ibuibu PKK memiliki alat teknologi yaitu handphone serta memiliki akun whatsapp; b) ibu-ibu PKK memahami kegunaan fitur-fitur yang ada di whatsapp guna membantu mereka dalam mempromosikan dan memasarkan barang yang akan mereka jual; c) ibu-ibu PKK yang masih belum mempunyai pengalaman atau mencoba berniaga dalam media sosial.

Mengapa kami menargetkan kegiatan ini kepada ibu-ibu PKK? Kegiatan sosialisasi ini ditargetkan kepada ibu-ibu PKK karena menurut kami ibu-ibu PKK merupakan ibu-ibu yang bukan merupakan wanita karir (tidak bekerja) dengan keadaan ekonomi yang berada dalam tingkat menengah hingga ke bawah. Selain sibuk dalam mengurus rumah tangga, ibu-ibu ini merupakan ibu-ibu yang aktif dalam mengikuti kegiatan yang ada dalam lingkungan PKK, seperti acara-acara yang diselenggarakan dari kelurahan atau RT dan RW setempat. Selain itu alasan kami menargetkan ibu-ibu PKK karena pasti ibu-ibu PKK tersebut tidak ingin hanya mengandalkan pemasukan dari gaji suami pasti mereka juga ingin memiliki pegangan atau keuangan tambahan entah untuk diri sendiri atau kebutuhan darurat yang ada dalam rumah tangga. Maka dari itu kami melakukan sosialisasi berniaga secara online yang mana kami harapkan dengan adanya sosialisasi ini dapat menjadi alternatif yang digunakan ibu-ibu tersebut utuk mendapatkan tambahan.

Dalam kegiatan sosialisasi yang tim kami lakukan, kami menggunakan metode klasikal, yang mana metode tersebut merupakan metode dengan tim kami yang menjadi narasumber dan sekaligus tim kami melakukan dan menjelaskan dengan cara simulasi dalam pemasaran produk dengan penyampaian yang dibantu dengan materi yang ada selama 45 menit selanjutnya dalam 20 menit terakhir merupakan kegiatan yang diisi dengan sharing dengan pengalaman antara tim kami dengan ibu-ibu PKK dalam menggunakan media sosial baik untuk berbelanja atau untuk berniaga.

\section{HASIL DAN PEMBAHASAN}

Dalam kegiatan pengabdian kepada masyarakat yang kami selenggarakan dengan tutorial berniaga dalam media sosial, telah menghasilkan beberapa hal sebagai berikut; 
a. Ibu-ibu PKK di wilayah Pondok Pinang RT010/RW01 ini, masih memiliki pengetahuan yang minim dalam berniaga secara online, dimana mereka belum pernah mencoba menggunakan metode tersebut, hanya ada beberapa yang sudah melakukan metode perdagangan online tersebut. Tetapi mereka paham dan tau dengan aplikasi-aplikasi media online yang menjadi wadah dalam berniaga online. Jadi, mereka selama ini hanya menjadi penikmat saja atau dapat dikatakan sebagai pembeli dalam berbelanja online.

b. Ditemukan juga ada ibu-ibu PKK yang masih berbisnis atau berjualan dengan cara konvensional, yaitu dengan membawa dan menawarkan dagangannya kepada tetanggatetangga setempat dengan menawarkan pembayaran yang dilakukan secara kredit atau bisa juga dibayar lunas pada saat itu.
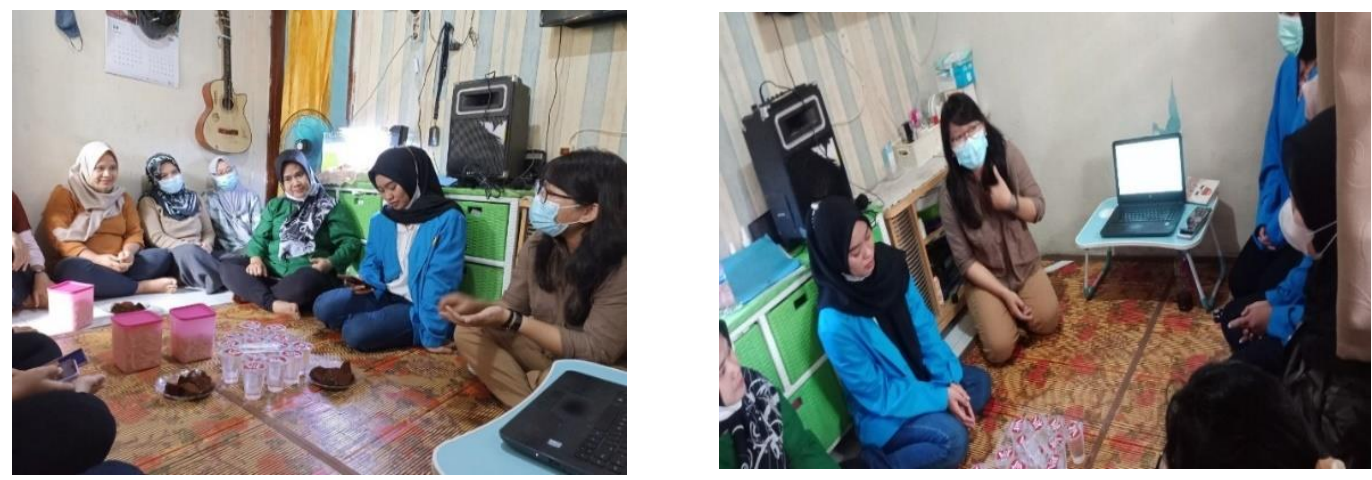

Gambar 1. Kegiatan Pengabdian kepada Masyarakat

Kegiatan pengabdian masyarakat ini kami lakukan dengan penyampaian awal mengenai bagaimana awal mula agar ibu-ibu dapat memulai bisnis oline dengan menentukan tujuan berdagang untuk apa, apakah ingin berdagang dengan jangka panjang yang mana jika ingin bertahan untuk jangka panjang diperlukan modal dan persiapan diri dengan matang dan pintarpintar dalam mengelola keuangan yaitu memisahkan antara kebutuhan untuk modal dan kebutuhan diri. Setelah mendapatkan keuntungan dari hasil bisnis online, tim kami juga memberi tips and trick yang dapat digunakan oleh ibu-ibu dalam mengatur keuangannya dengan cara menyisihkan 50-30-20 yang mana artinya disini 50\% dapat digunakan untuk kebutuhan seharihari, 30\% dapat digunakan untuk keinginan, dan 20\% sisanya dapat digunakan untuk ibu-ibu simpan dalam tabungan bank atau celengan yang nantinya dapat digunakan sebagai dana darurat atau untuk perputaran modal berjualan.

Selanjutnya, tim kami memberikan sosialisasi untuk ibu-ibu dapat menentukan jenis usaha apa yang cocok untuk diperdagangkan apakah usaha dalam kuliner, pakaian, atau alat-alat kebutuhan sehari-hari seperti alat dapur, elektronik, meja belajar, dll. Dalam berbisnis online ini tim kami juga menyarankan kepada ibu-ibu setempat jika ingin berjualan online tanpa mengeluarkan modal yang terlalu besar, bisa menjadi seorang reseller atau dropshiper yang mana reseller sendiri merupakan kita sebagai penjual menjualkan produk orang lain dengan menambahkan keuntungan yang kita inginkan misal, jika ibu A menjual daster dengan harga Rp 35.000 maka, ibu-ibu yang ingin menjadi reseller dapat menjualnya seharga Rp 50.000 maka dengan modal kecil tersebut di dapat keuntungan sebesar Rp 15.000 dengan menjualkan produk daster tersebut. Sedangkan menjadi dropshiper berarti jika Toko A menjual produk baju seharga Rp 50.000, kita sebagai dropshiper hanya perlu menawarkan produk kepada tetangga dengan harga yang sudah dilebihkan untuk keuntungan misal Rp 60.000, dan jika ada yang ingin membeli maka kita hanya perlu menerima uang pelanggan tersebut dan membelanjakannya kepada toko A tersebut senilai Rp 60.000, setelah itu toko A akan mengirimkan produk baju tersebut kepada pelanggan.

Setelah melakukan sosialisasi dalam pemilihan usaha yang cocok dan ingin berjualan tanpa modal tersebut, tim kami memberikan bagaimana cara pemasaran melalui media sosial agar dapat menarik calon pelanggan, misal kita dapat menggunakan fitur status whatsapp untuk memasang gambar atau foto detail produk yang kita jual. Misal, hias atau rapihkan packing dan edit foto sebaik dan semenarik mungkin tanpa menghilangkan kualitas asli agar dapat memikat 
hati pelanggan, karena dengan foto profuk yang menarik biasanya pelanggan akan tertarik juga untuk sekedar bertanya-tanya mengenai kuaifikasi barang yang kita jual tersebut

\section{KESIMPULAN}

Hasil penyuluhan dan pelatihan pada kegiatan pengabdian masyarakat ini menunjukan bahwa pelatihan ini merupakan langkah selanjutnya dengan berkembangnya jaman dan teknologi memulai bisnis online dengan menentukan tujuan serta memanfaatkan jejaring sosial yang ada untuk mempromosikan dan memasarkan barang/produk dalam dunia bisnis. Melakukan perencanaan keuangan agar memiliki tabungan untuk kebutuhan mendesak. pemanfaatan ini menggunakan jejaring sosial untuk kepentingan dalam bisnis yang disosialisasikan pada ibu-ibu PKK di Kelurahan Pondok Pinang, Jakarta Selatan dengan tujuan ibu-ibu PKK tersebut terinspirasi dan termotivasi agar semangat untuk mengasah kemampuan yang dimilikinya untuk menjalankan sebuah bisnis/usaha kecil-kecilan secara online untuk meningkatkan kebutuhan financial keluargannya. Memberikan wawasan tentang kewirausahaan untuk menumbuhkan kreatifitas dalam berjualan, untuk meningkatkan keterampilan dalam mempromosikan dan menawarkan produk agar menarik calon pelanggan.

Adapun saran yang dapat diberikan dalam pelaksanaan kegiatan yaitu, Sebelum melakukan pelatihan sebaiknya menanyakan terlebih dahulu kepada ibu-ibu PKK apakah sudah memanfaatkan jejaring sosial dalam kegiatan usahanya. tidak hanya melakukan pelatihan terhadap ibu-ibu PKK saja tetapi dari berbagai kalangan.

\section{REFERENSI}

Handayani, M., Sari, D. M., Eriva, C. Y. (2021). Program Peningkatan Kewirausahaan Melalui Media Digital Untuk Pondok Yatim Putri Human Initiative.

Haryadi, R. N., Anda Rojali, Khumidin, \& M. Fauzan. (2021). Sosialisasi Penggunaan Online Shop berbasis Website di UMKM Cimanggis. Jurnal Pengabdian Masyarakat Madani (JPMM), 1(1), 10-16. https://doi.org/10.51805/jpmm.v1i1.3

Gondokusumo R. 2016. 4 Manfaat Media Sosial untuk Program Digital Marketing Bisnis Anda.

Sunarsi, D., \& Sutoro, M. (2021). The Effect of Leadership Style and Digital Transformation on Financial Performance: An Empirical Study on Indonesian MSMEs. Review of International Geographical Education Online, 11(10), 548-556.

Ika Febrilia, Hafifah Nasution, Dwi Handarini. (2017) Pelatihan Penggunaan Jejaring Sosial Instagram Dalam Memasarkan Barang Pada Ibu-ibu PKK Di Kelurahan Rawamangun Jakarta Timur. 